\title{
Redescription of Desportesius brevicaudatus (Spirurida, Acuariidae) based on nematodes from Ixobrychus minutus (Aves, Ciconiiformes) from Bulgaria
}

\author{
Y. MUTAFCHIEV, B. B. GEORGIEV
}

Central Laboratory of General Ecology, Bulgarian Academy of Sciences, 2 Gagarin Street, 1113 Sofia, Bulgaria, E-mail: bbg@ecolab.bas.bg

\begin{abstract}
Summary
Desportesius brevicaudatus (Dujardin, 1845) is redescribed on the basis of light-microscopy and SEM observations on specimens collected from the oesophagus and under the lining of the gizzard of Ixobrychus minutus (Ardeidae) from Bulgaria. New metrical data expand the known ranges of variation of the measurements of the body, tail, cordons, oesophagus and spicules. New information is provided on the variation of the shape of the deirids, the structure of the vagina, the complexity of the cordons, the pattern of the cuticular striation and the shape of the postdeirids. Cordons are described as consisting of a single row of serrate cuticular plates and a longitudinal cuticular ridge along the outer rims of the cuticular plates. The cuticular ridge is interpreted as homologous to the outer row of plates in the cordons of the genera Acuaria, Cheilospirura and Echinuria.
\end{abstract}

Keywords: Nematoda; Spirurida; Desportesius brevicaudatus; morphology; Ixobrychus; Bulgaria

\section{Introduction}

The morphology of Desportesius brevicaudatus (Dujardin, 1845) has been studied by several authors (Skrjabin, 1917; Sobolev in Skryabin et al., 1965; Wong \& Anderson, 1986; Smogorzhevskaya, 1990). The previous redescriptions contained information about a small number of characters and paid little attention to the metrical data and their variation. No ultrastructural studies of this species have been carried out. During a survey of the acuariid nematodes from Bulgaria, we found D. brevicaudatus collected from Ixobrychus minutus (L.) from the vicinity of Sofia. The examination of these specimens by light microscopy and SEM allowed expanding knowledge on the morphology of the species. The aim of the present article is to provide a detailed morphological description of $D$. brevicaudatus.

\section{Material and Methods}

A sample of 1 female and 2 male nematodes were found in the oesophagus and under the lining of the gizzard of one Ixobrychus minutus on 6 May 1983 at the village of Negovan. Another sample of 3 males and 8 females was obtained from a bird of the same species on 19 May 1983 at the village of Chelopechene (both localities near Sofia). The nematodes were fixed and preserved in $70 \%$ ethanol. For light microscopy, specimens were cleared and examined as temporary mounts in glycerine. Specimens used for SEM observations were 1 male and 2 females. They were transferred from $70 \%$ ethanol to $40 \%$ ethanol $(10 \mathrm{~min})$, rinsed in $0.1 \mathrm{M}$ cacodylate buffer (twice by $10 \mathrm{~min}$ ), postfixed in $1 \% \mathrm{OsO}_{4}$ for $2 \mathrm{~h}$, dehydrated in an ethanol series and critical-point dried with $\mathrm{CO}_{2}$ by BAL-TEC CPD 030 . Specimens were coated with gold-palladium in sputter coater Polaron SC7640 and examined using a LEO microscope at $10 \mathrm{kV}$.

Metrical data are presented as the range, with the mean and the number of measurements taken (n) in parentheses. Measurements are in micrometres except otherwise stated. The following indices were used: cordon length/body length $=\mathrm{I}_{\mathrm{CL} / \mathrm{BL}}$; length of muscular oesophagus/length of glandular oesophagus $=\mathrm{I}_{\mathrm{mOE} / \mathrm{gOE}}$; length of oesophagus/body length $=\mathrm{I}_{\mathrm{OE} / \mathrm{BL}}$; length of caudal alae/body length $=\mathrm{I}_{\mathrm{CA} / \mathrm{BL}}$; length of left spicule/length of right spicule $=$ $\mathrm{I}_{\mathrm{LSP} / \mathrm{RSP}}$; distance from vulva to posterior end/body length $=$ $\mathrm{I}_{\mathrm{V} / \mathrm{BL}}$.

Voucher specimens are deposited in the helminthological collections of the Museum für Naturkunde der HumboldtUniversität zu Berlin, no ZMB Vermes, Entozoa 7446, and the Central Laboratory of General Ecology, Bulgarian Academy of Sciences, Sofia (CLGE), nos N000.329; N000.846; N000.331; N000.850; N001.038 two female specimens, SEM stub; N001.039 one male specimen, SEM stub. 

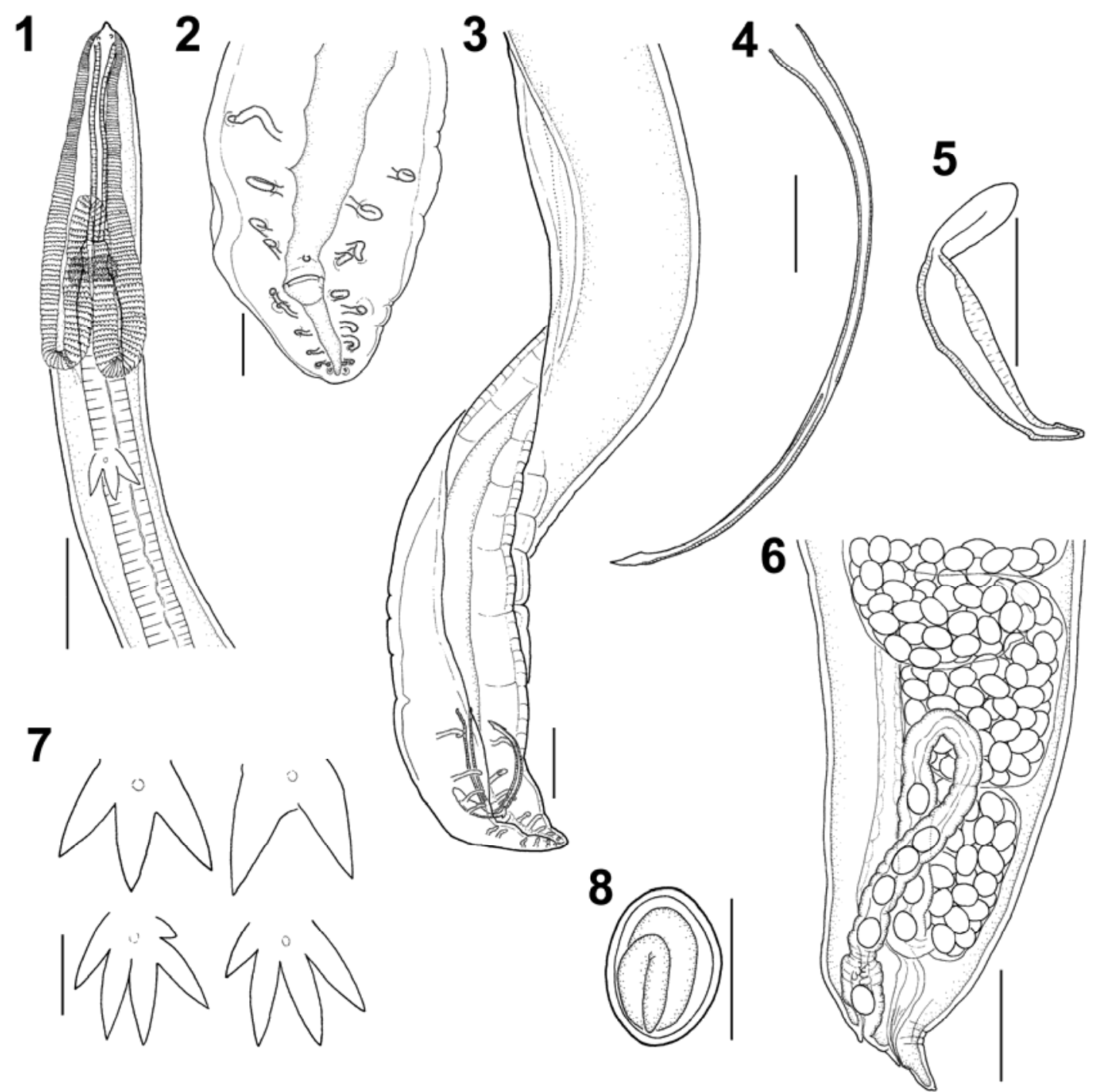

Figs. 1 - 8. Desportesius brevicaudatus. Fig. 1. Anterior end, male, lateral view. Fig. 2. Caudal end, male, ventral view. Fig. 3. Posterior end, male. Fig. 4. Left spicule, sinistral view. Fig. 5. Right spicule, dextral view. Fig. 6. Posterior end, female, lateral view. Fig. 7. Deirids. Fig. 8. Egg. Scale-bars $=100 \mu \mathrm{m}(1,3,6) ; 50 \mu \mathrm{m}(2,4,5) ; 25 \mu \mathrm{m}(7,8)$.

\section{Results}

Desportesius brevicaudatus (Dujardin, 1845) Skryabin, Sobolev \& Ivashkin, 1965 (Figs. 1 - 17)

Syns Dispharagus brevicaudatus Dujardin, 1845; Histiocephalus brevicaudatus (Dujardin, 1845) Diesing, 1851; Acuaria (Synhimantus) brevicaudata (Dujardin, 1845) Railliet, Henry \& Sisoff, 1912; Synhimantus brevicaudatus (Dujardin, 1845) Gedoelst, 1919; Synhimantus (Desportesius) brevicaudatus (Dujardin, 1845) Gedoelst, 1919: Chabaud \& Campana (1949); Spiroptera triaenophora Mehlis in Creplin, 1846.

General. Medium-sized acuariid nematode. Anterior end with 2 triangular pseudolabia, each bearing single amphid and pair of papillae (Figs. $10-12$ ). Cordons arise dorsally and ventrally between pseudolabia, extending posteriorly beyond nerve ring, recurrent in anterior direction and anastomosing laterally at level of posterior part of buccal cavity (Figs. 1, 9). Each cordon consisting of a single row of cuticular plates and longitudinal cuticular ridge along outer rims of plates; cuticular plates with width increasing in posterior direction and with serrate posterior rim bearing $10-12$ spines in widest part of cordon (Fig. 13); cuticular plates and longitudinal ridge delimiting deep, almost closed longitudinal canal. Deirids very big, flat, usually tricuspid, sometimes with two, four or five cusps (Figs. 7, 9). Postdeirids small, c.3 long, bifurcate (Fig. 15). Cuticular striations present, interrupted along lateral sides of body (Fig. 14). Excretory pore situated close to posterior end of cordons (Fig. 13). Buccal cavity elongate. Nerve ring surrounding narrow anterior portion of muscular oesophagus (Fig. 1).

Male $(\mathrm{n}=5$, except otherwise stated). Body length $6.4-$ $9.0 \mathrm{~mm}$ (7.6 mm). Maximum width $174-206$ (191), about 


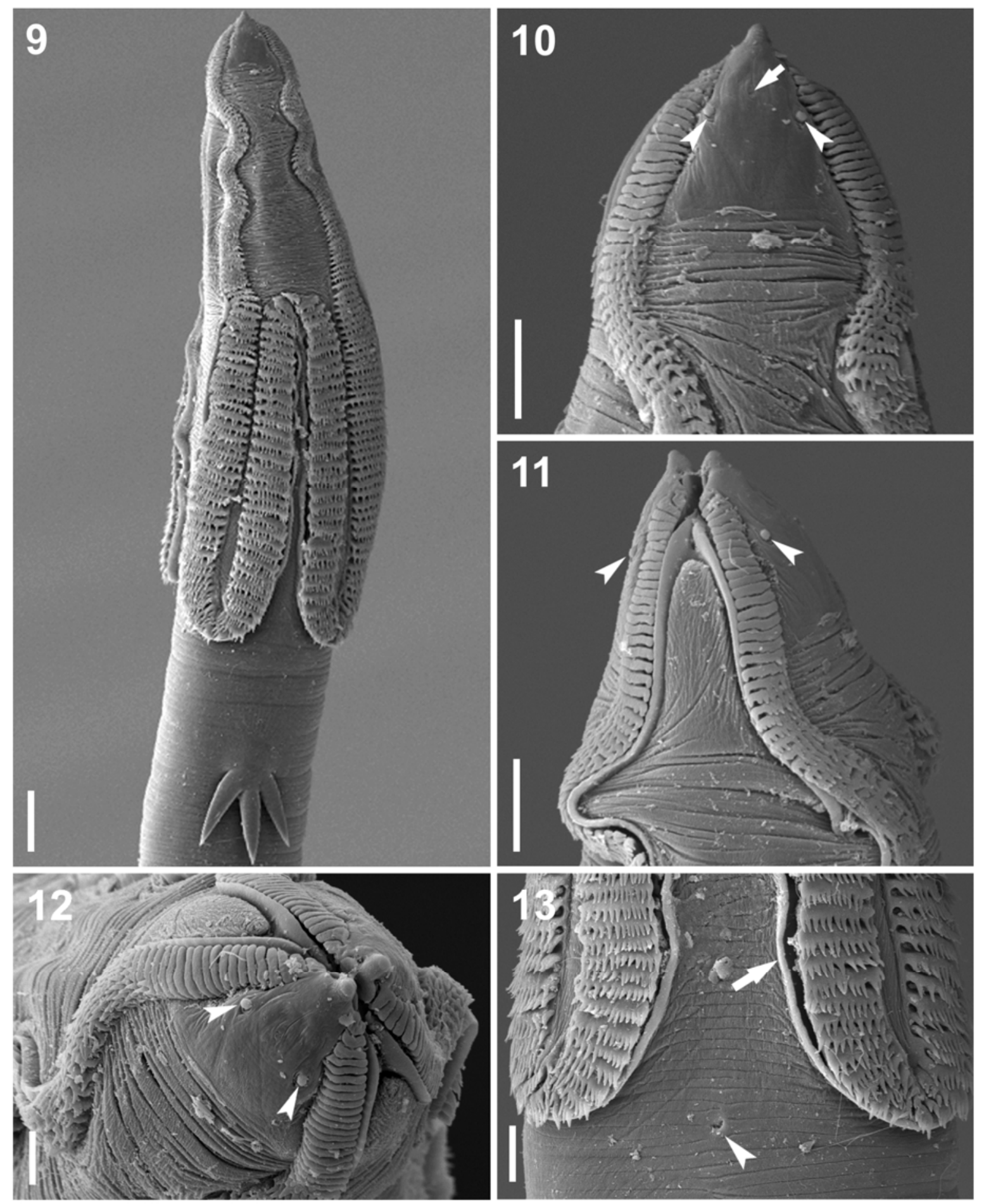

Figs. 9 - 13 . Desportesius brevicaudatus, female, SEM. Fig. 9. Anterior end, lateral view. Fig. 10. Cephalic end, lateral view; note the cephalic papillae (arrowheads) and the amphid (arrow); Fig. 11. Cephalic end, ventral view; note the cephalic papillae (arrowheads). Fig. 12. Cephalic end, apical view; note the cephalic papillae (arrowheads). Fig. 13. Posterior region of the cordons, note the excretory pore (arrowhead) and the longitudinal ridge of the cordon (arrow). Scale-bars $=20 \mu \mathrm{m}(9) ; 10 \mu \mathrm{m}(10,11,13) ; 5 \mu \mathrm{m}$ (12).

mid-body. Tail 88 - 99 (93) long. Body width at level of cloaca 45 - 63 (54). Cordons 215 - 282 (261) long, recurrent in anterior direction to $106-147$ (134) from anterior body end, maximum 18 - 23 (20) wide. Deirids and excretory pore at $295-362$ (330) and $259-295$ (280), res- pectively, from anterior end. Deirids $44-46$ (45) long. Left postdeirid and right postdeirid at $2.7-3.4 \mathrm{~mm}$ (3.1 $\mathrm{mm}, \mathrm{n}=4) \mathrm{mm}$ and $1.8-2.3 \mathrm{~mm}(2.0 \mathrm{~mm}, \mathrm{n}=4)$, respectively, from anterior end. Buccal cavity $167-204$ (187) long (measured from anterior body end), 9 - 12 (10) wide. 

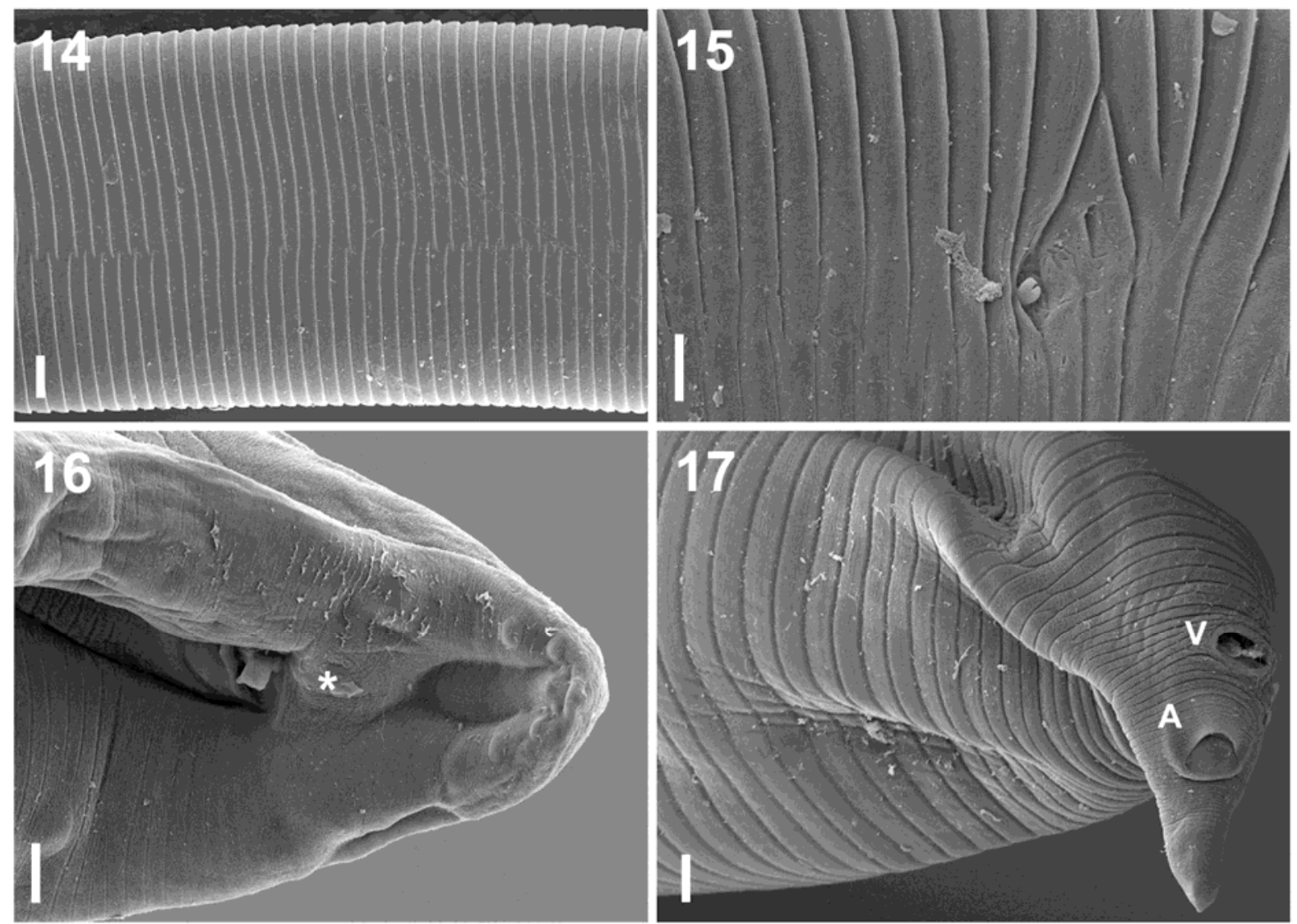

Figs. 14-17. Desportesius brevicaudatus, SEM. Fig. 14. Cuticular striations at the level of the mid-body, lateral view. Fig. 15. Postdeirid. Fig. 16. Caudal end, male, ventral view; note the cupola situated posteriorly to cloaca (asterisk). Fig. 17. Posterior end, female, showing the anus (A) and the vulva (V). Scale-bars $=20 \mu \mathrm{m}(14) ; 10 \mu \mathrm{m}(15-17)$.

Muscular oesophagus 624 - 738 (696) long, $34-41$ (37) wide. Glandular oesophagus 1756 - 2342 (2 013) long, 63 - 82 (70) wide. Nerve ring at 163 - 218 (199) from anterior end. Cuticle $11-16$ thick. Distance between cuticular striations 9 - 13. Caudal alae 1155 - 1728 (1 455) long. Well-expressed cupola present ventrally, just posterior to cloaca (Figs. 2, 16). Single median sessile precloacal papilla present. Nine pairs of pedunculate caudal papillae, 4 precloacal and 5 postcloacal (Figs. 2, 3); postcloacal pairs of pedunculate papillae not grouped. Sixth pair of postcloacal papillae sessile, smaller, situated between bases of last pedunculate papillae. Left spicule $340-371$ (355, $\mathrm{n}=3$ ) long, 7 - 9 (8) wide (Fig. 4). Right spicule 112 $-129(118, \mathrm{n}=3)$ long, $19-24(21, \mathrm{n}=3)$ wide (Fig. 5). $\mathrm{I}_{\mathrm{CL} / \mathrm{BL}} 0.030-0.042(0.035) ; \quad \mathrm{I}_{\mathrm{mOE} / \mathrm{gOE}} 0.315-0.389$ (0.349); $\mathrm{I}_{\mathrm{OE} / \mathrm{BL}} 0.319-390(0.357) ; \mathrm{I}_{\mathrm{CA} / \mathrm{BL}} 0.176-0.210$ (0.191); I ISP/RSP $2.75-3.28(3.02, \mathrm{n}=2)$.

Female $(\mathrm{n}=8$, except otherwise stated). Body length $7.6-$ 9.3 (8.4) mm. Maximum width 255 - 335 (291), in posterior quarter of body. Tail $30-45$ (37) long. Body width at anus $23-29$ (26), at vulva $43-61$ (52). Cordons $206-$ 313 (253) long, recurrent in anterior direction to $88-156$ (111) from anterior body end, maximum 21 - 27 (24) wide. Deirids and excretory pore at 228 - 398 (299) and 165 - 291 (236), respectively, from anterior extremity.
Deirids $36-47$ (45) long. Left postdeirid and right postdeirid at $1.9-3.0 \mathrm{~mm}(2.5 \mathrm{~mm})$ and $1.3-2.0 \mathrm{~mm}(1.6$ $\mathrm{mm})$, respectively, from anterior extremity. Buccal cavity 167 - 206 (181) long (measured from anterior body end), 11-16 (14) wide. Muscular oesophagus 675 - 825 (721) long, 36 - 48 (42) wide. Glandular oesophagus $1705-2$ 215 (1 959) long, $63-88$ (78) wide. Nerve ring at $159-$ 224 (184) from anterior extremity. Cuticle $9-15$ thick; distance between cuticular striations $13-15$. Vulva at $59-$ 71 (64) from posterior extremity; body sharply narrowing posterior to vulva (Figs. 6, 17). Uterus monodelphic. Vagina vera short, directed anteriorly, separated from vagina uterina by thick cuticular folds. Vagina uterina long, with well-developed circular musculature of walls. Eggs oval, $27-29 \times 20-21(28 \times 21, \mathrm{n}=20)$, containing fully-developed embryo (Fig. 8). $\mathrm{I}_{\mathrm{CL} / \mathrm{BL}} 0.025-0.045$ (0.032); $\mathrm{I}_{\mathrm{mOE} / \mathrm{gOE}} 0.324-0.433(0.366) ; \mathrm{I}_{\mathrm{OE} / \mathrm{BL}} 0.287-0.421$ $(0.333) ; \mathrm{I}_{\mathrm{V} / \mathrm{BL}} 0.007-0.010(0.008)$.

\section{Discussion}

The genus Desportesius Chabaud \& Campana, 1949 was erected as a subgenus of Synhimantus Railliet, Henry \& Sisoff, 1912; the authors placed 7 species in the new subgenus, mostly parasitic in ardeid birds (Chabaud \& Cam- 
pana, 1949). The subgenus was elevated to the generic level by Skryabin et al. (1965). Subsequent authors (Chabaud, 1975; Wong \& Anderson, 1986; Smogorzhevskaya, 1990) also recognised Desportesius as a distinct genus.

Desportesius brevicaudatus (Dujardin, 1845) has been recorded as a parasite of birds of the family Ardeidae: Botaurus stellaris (L.) (type host), Ixobrychus minutus, Egretta garzetta (L.) and Ardea cinerea L.; all the records were from Palaearctic: France, Germany, Poland, Romania, Bulgaria, Ukraine, Russia (Black Sea coast) and Tajikistan (for surveys, see Wong and Anderson, 1986; Smogorzhevskaya, 1990). It has been reported from Falco tinnunculus L. (Accipitriformes, Falconidae) and B. stellaris in Bulgaria (Petrova, 1984). The record from the former host is unusual, since the remaining findings of this nematode species were from ardeid birds only. Unfortunately, Petrova's (1984) material of this species was not available for revision for the purposes of the present study and we consider it doubtful. Therefore, the host range of $D$. brevicaudatus is considered here as restricted to ardeid birds.

Wong and Anderson (1986) revised the genus Desportesius and redescribed D. brevicaudatus on the basis of one male specimen from the type material. The specimens from Bulgaria correspond well to their redescription in the body length, cordon length (data from the illustration), length of muscular and glandular oesophagus as well as the shape of the spicules and the arrangement of the caudal papillae. The male specimens from Bulgaria possess a longer tail ( 88 - 99 vs 55) and longer left and right spicules $(340-371$ vs 271 and $112-129$ vs 95 , respectively) but similar ratio, $\mathrm{I}_{\mathrm{LSP} / \mathrm{RSP}} 2.75-3.28$ in our material vs 2.85 in the type specimen. On the basis of these comparisons, we identify the material from Bulgaria as $D$. brevicaudatus.

The samples from Bulgaria correspond well in their measurements (except for the length of the cordons) with the material from I. minutus from Ukraine (Smogorzhevskaya, 1990) (Table 1).

Most of the previous descriptions of $D$. brevicaudatus

Table 1. Comparative metrical data of Desportesius brevicaudatus from various hosts and localities (in micrometres except otherwise stated).

\begin{tabular}{|c|c|c|c|c|c|}
\hline Source & $\begin{array}{c}\text { Wong and } \\
\text { Anderson } \\
\text { (1986) }\end{array}$ & $\begin{array}{l}\text { Skrjabin } \\
(1917)\end{array}$ & $\begin{array}{l}\text { Sobolev in } \\
\text { Skryabin et } \\
\text { al. (1965) }\end{array}$ & $\begin{array}{c}\text { Smogorzhevskaya } \\
\text { (1990) }\end{array}$ & Present study \\
\hline Host & $\begin{array}{l}\text { Botaurus } \\
\text { stellaris }\end{array}$ & $\begin{array}{l}\text { Botaurus } \\
\text { stellaris }\end{array}$ & $\begin{array}{l}\text { Host not } \\
\text { mentioned }\end{array}$ & Ixobrychus minutus & Ixobrychus minutus \\
\hline Locality & France (?) & Russia & Russia & Ukraine & Bulgaria \\
\hline Male & $\mathrm{n}=1$ & & & & $\mathrm{n}=5$ \\
\hline Body length (mm) & 7.3 & - & 10.0 & $7.2-9.0$ & $6.4-9.0(7.6)$ \\
\hline Maximum body width & 130 & - & 160 & $130-172$ & $174-206(191)$ \\
\hline Tail, length & 55 & - & 63 & - & $88-99(93)$ \\
\hline Cordons, length & $223^{* * * *}$ & - & 228 & 292 & $215-282(261)$ \\
\hline $\begin{array}{l}\text { Deirids from anterior end, } \\
\text { distance }\end{array}$ & 257 & - & - & - & $295-362(330)$ \\
\hline $\begin{array}{l}\text { Excretory pore from } \\
\text { anterior end, distance }\end{array}$ & 212 & - & - & - & $259-295(280)^{*}$ \\
\hline Buccal cavity, length & 152 & - & 170 & $160-200$ & $167-204(187)$ \\
\hline $\begin{array}{l}\text { Muscular oesophagus, } \\
\text { length }\end{array}$ & 700 & - & 650 & $700-800$ & $624-738(696)$ \\
\hline $\begin{array}{l}\text { Glandular oesophagus, } \\
\text { length (mm) }\end{array}$ & 2.0 & - & 2.2 & $2.0-2.2$ & $1.8-2.3(2.0)$ \\
\hline Left spicule, length & 271 & - & 110 & $220-370$ & $340-371(355)^{* *}$ \\
\hline Right spicule, length & 95 & - & 60 & $72-100$ & $112-129(118)^{* *}$ \\
\hline Female & & & & & $\mathrm{n}=8$ \\
\hline Body length (mm) & - & $7.5-8.5$ & - & $9.0-13.0$ & $7.6-9.3(8.4)$ \\
\hline Maximum body width & - & 290 & - & 304 & $255-335(291)$ \\
\hline Tail, length & - & 68 & - & - & $30-45(37)$ \\
\hline Cordons, length & - & 425 & - & $340-400$ & $206-313(253)$ \\
\hline $\begin{array}{l}\text { Deirids from anterior end, } \\
\text { distance }\end{array}$ & - & 560 & - & - & $228-398$ (299) \\
\hline $\begin{array}{l}\text { Excretory pore from } \\
\text { anterior end, distance }\end{array}$ & - & - & - & - & $165-291(236)$ \\
\hline Buccal cavity, length & - & 210 & - & $200-220$ & $167-206(181)$ \\
\hline $\begin{array}{l}\text { Muscular oesophagus, } \\
\text { length }\end{array}$ & - & 850 & - & $714-800$ & $675-825(721)$ \\
\hline $\begin{array}{l}\text { Glandular oesophagus, } \\
\text { length }(\mathrm{mm})\end{array}$ & - & - & - & 2.3 & $1.7-2.2(2.0)$ \\
\hline $\begin{array}{l}\text { Vulva from posterior end, } \\
\text { distance }\end{array}$ & - & $600^{* * *}$ & - & $60-70$ & $59-71(64)$ \\
\hline
\end{tabular}


provided inadequate data about its metrical characters, obviously based on a small number of specimens (Table 1). The present study expanded the known ranges of variation of the body length and width, length of the tail and oesophagus, length and width of the cordons, size of the deirids and size of the spicules. In addition, we provide new data on the detailed structure of the cordons, the pattern of cuticular striation, the shape of the postdeirids, the variations in the shape of the deirids and the structure of the vagina.

The only previous SEM study of a species of the genus Desportesius is that on D. invaginatus (von Linstow, 1901) from Bubulcus ibis (L.) (=Ardeola ibis) from Egypt (Varjabedian, 2006). The published description and illustrations provide limited possibilities for comparisons. From the illustrations, it is seen that the widest cuticular plates of cordons in D. invaginatus bear c.20 posterior spines while, according to our observations, those in D. brevicaudatus have $10-12$ spines only. In our material, we did not observe irregularly distributed cuticular bosses situated on the lateral sides of the posterior part of females and transverse annulations ("each annulus is striated") as described by Varjabedian (2006). Unfortunately, the illustrations do not allow us to judge whether these differences are specific characters of the species compared or if they are due to the processing of specimens of $D$. invaginatus.

Our SEM study revealed the particular structure of the cephalic cordons of $D$. brevicaudatus (see above). In some acuariid nematodes, each cordon consists of two longitudinal rows of similar plates, with a longitudinal canal situated between them; such an arrangement has been described in Acuaria anthuris (Rudolphi, 1819) (see Frantová, 2002), Cheilospirura hamulosa (Diesing, 1851) (see Gomes et al., 2004) and Echinuria uncinata (Rudolphi, 1819) (see Kennedy et al., 1973). There is no outer row of plates in D. brevicaudatus; it seems that the outer plates have merged to form a longitudinal ridge that externally delimits the longitudinal canal in this species. A similar structure of the cordons has been illustrated for Syncuaria plegadisi Digiani, 1999 and Decorataria diacantha (Petter, 1961) (see Digiani, 1999), S. mackoi Mutafchiev \& Georgiev, 2008 (see Mutafchiev \& Georgiev, 2008a), Decorataria decorata (Cram, 1927) (Mutafchiev \& Georgiev, 2008b), Skrjabinocerca canutus Diaz, Cremonte, Navone \& Laurenti, 2005 (see Diaz et al., 2005). Chabaud \& Campana (1949) commented on the differences in the structure of the cordons of the Echinuriinae and Desportesius; on the basis of light-microscopy observations on Desportesius spinulatus (Chabaud \& Campana, 1949) Chabaud, 1950 (a junior synonym of $D$. invaginatus, see Wong \& Anderson, 1986), they considered that the similar configurations of the cordons in these groups were results of convergent evolution. The homology of the outer longitudinal row of plates and the outer longitudinal ridge might be important in view of its application in phylogenetic studies of acuariids. Mawson (1982) emphasised the importance of the complexity of the cordon structure, in addition to their configuration, for the taxonomy of this family.

\section{Acknowledgements}

SEM observations were carried out using facilities of the Museum für Naturkunde der Humboldt-Universität zu Berlin in the course of a research visit of the senior author granted by Synthesys DE-TAF-3124 (EC FP6) and kindly hosted by Dr B. Neuhaus. Mrs G. Drescher of the same museum provided valuable assistance with the preparation of specimens for SEM studies. We are also grateful to Professor Z. Swiderski (Warszawa) for kindly providing a copy of a paper from an obscure journal and to Dr. P. N. Nikolov (Sofia) for reading the manuscript.

\section{References}

Chabaud, A.-G. (1975): Keys to the Genera of the Order Spirurida. Part 2. Spiruroidea, Habronematoidea and Acuarioidea. In Anderson, R. C., ChabAud, A.-G. \& Willmott, S. (Eds.): CIH Keys to the Nematode Parasites of Vertebrates, Vol. 3, CAB, Farnham Royal, Bucks.

Chabaud, A.-G., CAmpana, Y. (1949): A propos d'une variété nouvelle de Synhimantus equispiculatus Wu \& Liu, 1943. Création d'un nouveau sous-genre (Desportesius) n. subgen. Ann. Parasitol. Hum. Compar., 24: 77 - 92

Diaz, J. I., Cremonte, F., Navone, G. T., Laurenti, S. (2005): Adults and larvae of Skrjabinocerca canutus n. sp. (Nematoda: Acuariidae) from Calidris canutus rufa (Aves: Scolopacidae) on the southern Southwest Atlantic coast of South America. Syst. Parasitol., 60: 113 - 123

Digiani, M. C. (1999): First report of the genus Syncuaria (Nematoda: Acuariidae) in Argentina, with description of a new species. Folia Parasitol., 46: 139 - 144

Dujardin, F. (1845): Histoire Naturelle des Helminthes ou vers intestinaux. Paris

FRANTOVÁ, D. (2002): On the morphology and surface ultrastructure of some parasitic nematodes (Nematoda) of birds (Aves). Acta Soc. Zool. Bohemoslov., 66: 85 - 97

Gomes, D. C., Menezes, R. C., Vicente, J. J., LAnfredi, R. M., PINTO, R. M. (2004): New morphological data on Cheilospirura hamulosa (Nematoda, Acuarioidea) by means of bright-field and scanning electron microscopy. Parasitol. Res., 92: $225-231$

Kennedy, E. K., Welch, H. E., Dick, T. A. (1973): Cordon and spine ultrastructure of the waterfowl parasite Echinuria uncinata (Rudolphi, 1819) Soloviev, 1912 (Spirurida: Nematoda). Can. J. Zool., 51: 1133 - 1137 Mawson, P. M. (1982): Some Acuariinae (Nematoda) from Australian birds. T. Roy. Soc. South. Aust., 106: $19-$ 30

Mutafchiev, Y., Georgiev, B. B. (2008a): A new acuariid nematode, Syncuaria mackoi n. sp. (Spirurida), from Ciconia nigra (L.) (Ciconiiformes: Ciconiidae) in Europe. Syst. Parasitol., 70: $71-79$

MutafChieV, Y., GeorgieV, B. B. (2008b): Redescription of Decorataria decorata (Spirurida, Acuariidae) based on nematodes from Podiceps cristatus and P. grisegena (Aves, Podicipediformes) from Bulgaria. Acta Parasitol. 53: 158 - 164 
Petrova, K. (1984): On Nematoda from wild birds in Bulgaria. In VAsileV, I. (Ed.): Fauna, Taxonomy and Ecology of Helminths of Birds. Izdatelstvo na Balgarskata Akademiya na Naukite, Sofia (In Bulgarian)

Railliet, A., Henry, A., Sisoff, P. (1912): Sur les affinités des dispharages (Acuaria Bremser), nematodes parasites des oiseaux. C. R. Soc. Biol., 73: $622-624$

SKRJABIN, K. I. (1917): Sur quelques nematodes des oiseaux de la Russie. Parasitology, 9: 461 - 481

Skryabin, K. I., Sobolev, A. A., IVAshkin, V. M. (1965): Spirurata of Animals and Man and the Diseases Caused by Them. Spirurata Part 3, Acuarioidea. In SkryABIN, K. I. (Ed.): Osnovy Nematologii. Vol. 14.
Nauka, Moscow (In Russian)

Smogorzhevskaya, L. A. (1990): Nematodes. Part 3. Acuarioidea. In SHARPILO, V. P. (Ed.): Fauna Ukrainy. Vol. 32. Naukova Dumka, Kiev (In Russian)

VARJABEDIAN, K. G. (2006): An ultrastructural study on Desportesius invaginatus (Nematoda, Acuariidae) from Ardeola ibis ibis in Egypt. J. Egypt. Soc. Parasitol., 36: $149-157$

Wong, P. L., Anderson, R. C. (1986): Revision of the genus Desportesius Chabaud and Campana, 1949 (Nematoda: Acuarioidea) mainly from the gizzard of ciconiiform birds. Can. J. Zool., 64: $2520-2530$ 